\title{
An Empirical Study of the Moderator Effect of Entrepreneurial Orientation on the Relationship between Environmental Turbulence and Innovation Performance in Five-star Hotels in Jordan
}

\author{
Mohammad AL- Nuiami ${ }^{1}$, Wael Mohamad Subhi Idris ${ }^{2}$, Fayiz Abdelrahman Moh'd AL-Ferokh ${ }^{3} \&$ Mah'd Hussein $^{\prime}$ \\ Moh'd Abu Joma $^{2}$ \\ ${ }^{1}$ Managerial Information system \& Data Analysis, MEU University, Amman, The Hashemite Kingdom of Jordan \\ ${ }^{2}$ Business Administration, Jinan University (Tripoli - Lebanon), The Hashemite Kingdom of Jordan \\ ${ }^{3}$ Business Administration, W.I.S.E University (Amman - Jordan), The Hashemite Kingdom of Jordan \\ Correspondence: Wael Mohamad Subhi Idris, PHD Student, Business Administration, Jinan University (Tripoli - \\ Lebanon), The Hashemite Kingdom of Jordan. E-mail: Active.strategy@hotmail.com
}

Received: January 23, 2014

Accepted: March 3, 2014

Online Published: March 8, 2014

doi:10.5430/ijba.v5n2p111

URL: http://dx.doi.org/10.5430/ijba.v5n2p111

\begin{abstract}
Purpose: This paper aims to examine the Moderator Effect of Entrepreneurial Orientation on the relationship between Environmental Turbulence and Innovation Performance in five-star hotels in Jordan

Design / methodology: The study involves a questionnaire-based survey of managers and heads of sections from five star hotels in Amman capital at Jordan. A total of (135) surveys from (13) five star hotels were valid for analysis towards achieving the objectives of this study. Multiple regression analysis and structural equation modeling was performed to understand the relationship and effects among study variables.

Findings: The results show that Environmental Turbulence (Environmental Dynamism, Environmental Complexity and Environmental Predictability) has a significant positive effect on Innovation Performance at five star hotels in Amman capital of Jordan. Entrepreneurial Orientation, also, plays a positive indirect role in the relationship between Environmental Turbulence and Innovation Performance at five star hotels in Amman capital of Jordan.

Research limitation: This study only covered an incommodious part in the field of strategic management and organization theory. Particularly, it displays the important role of Entrepreneurial Orientation in the relationship between Environmental Turbulence and Innovation Performance.

Research implications: The study helps managers and decision makers to understand the role of Entrepreneurial Orientation to increase Innovation Performance and the effect of Environmental Dynamism, Complexity and Predictability.

Originality / value: The study explores the researcher's perspective orientations about environmental turbulence and Entrepreneurial Orientation and their role in increasing and maintenance of innovation performance.

Keywords: environmental turbulence, entrepreneurial orientation, innovation performance, five star hotels and Jordan

\section{Introduction}

Tourism is described as the industry of the future. It is one of the three most important industries which is the driving force of the economics of services industry in the twenty-first century. The tourism industry is unique in that it has the fastest growth and development when compared to all other industries. This in turn provides them with comparative advantages and makes them more competitive.

Tourism does not only impacts economically; it also plays an important role in various aspects of society. Indeed, tourism has a social importance of how it plays an important role in improving the living conditions of the population through increased income and employment. It also encourages the integration of local communities and expanding people's participation in tourism activities. The process of tourism planning also encourages greater contributions of local community members in planning and tourism development.
\end{abstract}


As a result of Jordanian economy attend the fundamental shifts in journey development and future orientations toward Tourism sector through different stages of development that regarded a long term motivated for economic growth in Jordan. While the Jordanian National Strategy for Tourism (2011 to 2015) clarifies that the most important strategic objective is establishing a modern and sophisticated tourism industry which meets the highest international standards and specifications.

Based on the above the tourism sector in Jordan is facing a variety of challenges despite the stable growth. Current challenges arose in the hotel industry in Jordan, despite its growth, as a result of some factors, whether internal or external, which affect the performance. For instant, intense competition is considered an external factor impacting the performance. An indication shows that the basic problem that is linked to the Jordanian Hospitality business is the concurrence happening among hotels that are star-rated and those that are not. Such concurrence happens due to extra provision of hotels, hotel evolvement regulations and the standards of the service. Thus, in order to survive in the business competition and qualify the operational, the five star hotels in Jordan should present good service with high quality.

There's a current competition scene taking place, as well as a rapid revolution of information technology with the globalization of the market, presents huge challenges facing business organizations in the market. Business organizations in the globalization age are keen on accomplishing a broader level of producing or the accumulating of tangible and intangible assets to create strategic competencies. Accomplish high level of performance and superiority on the competitor's competencies and adaptation with cumulative dynamism of competitive environments needed from business organizations to take into consideration more on their external competitive environment to render more appended customer value, firm distinction and extendibility, and to take into consideration more on environmental turbulence. Therefore environmental turbulence according to Volberda \& Van Bruggen (1997: 137) is a dynamic, unpredictable, expanding, fluctuating environment; it is an environment in which the components are marked by change.

There's a label that has been used as a reference to the organizations entrepreneurial attitude and conduct of manners in an intense competitive surrounding; the label is "organizations entrepreneurial orientation". The first model of entrepreneurial orientation which was presented by researchers was composed of five dimensions - innovativeness, risk taking, autonomy, proactiveness and competitive aggressiveness. Business organizations must handle these dimensions in order to maintain their position and grow in the current increasingly dynamic and competitive environment.

Consequently, the value of this research is great for the industry of tourism in Jordan, and specifically hotels that are ranked as five-star, because this sector of the industry adds a great ratio to the gross domestic product (GDP). And as of the recognition of environmental turbulence is a main element in the strategic success through developing performance, the main purpose of this study is to test the moderator effect of entrepreneurial orientation on the relationship between environmental turbulence and innovation performance in hotels of five star ranking in Jordan. This study took place in five star hotels; because of the different services provided, the environmental turbulence was taken under account. It also zooms in specifically on environmental turbulence: Dynamism (Intensity of Changes and Frequency of Changes), Complexity (Number and Relatedness of Elements) and Predictability (availability of Information and Predictability of Changes) as well as Entrepreneurial Orientation and Innovation Performance.

\subsection{Objective of the Study}

The aim of this study is therefore to empirically test the moderator effect of entrepreneurial orientation on the relationship between environmental turbulence and innovation performance in five-star hotels in Jordan through:

1) Examine the direct effect of Environmental Turbulence (Environmental Dynamism, Environmental Complexity and Environmental Predictability) on Innovation Performance in five-star hotels in Jordan.

2) Investigate the indirect effect of Environmental Turbulence (Environmental Dynamism, Environmental Complexity and Environmental Predictability) on Innovation Performance via Entrepreneurial Orientation in five-star hotels in Jordan.

\subsection{Significance of the Study}

The significance of the current study stems from the limitation of Arab studies that addressed the environmental turbulence and entrepreneurial orientation, highlights the nature of environmental turbulence in the tourism sector, especially five star hotels, and contributes to develop a working mechanism of five-star hotels and to maintain continuity. Also, this study derives its empirical significance from helping employees in the hospitality tourism 
sector to understand the importance of both environmental turbulence and entrepreneurial orientation in achieving high performance levels.

\section{Literature Review and Hypotheses Development}

\subsection{Environmental Turbulence}

As expressed by Boyne and Meier (2009: 801) Turbulence is one factor of general models of the task environment that constrains organizational behavior and performance. While Ansoff and McDonnell (1990) defined 'environmental turbulence' as a group measure of the changeability and predictability of the firm's environment. On the other hand, Vorhies (1998) focused on the definition of environmental turbulence in dynamism involving rapid, unexpected change in the organization's environmental sub dimensions such as technology, customers, competitors, government regulations and new product launches. While, Smith, et..al. (1999) defines environmental turbulence as a function of the complexity, dynamism and uncertainty in that environment. Volberda \& Van Bruggen (1997: 137-138) determine the three dimension of environmental turbulence as illustrative in Figure 1.

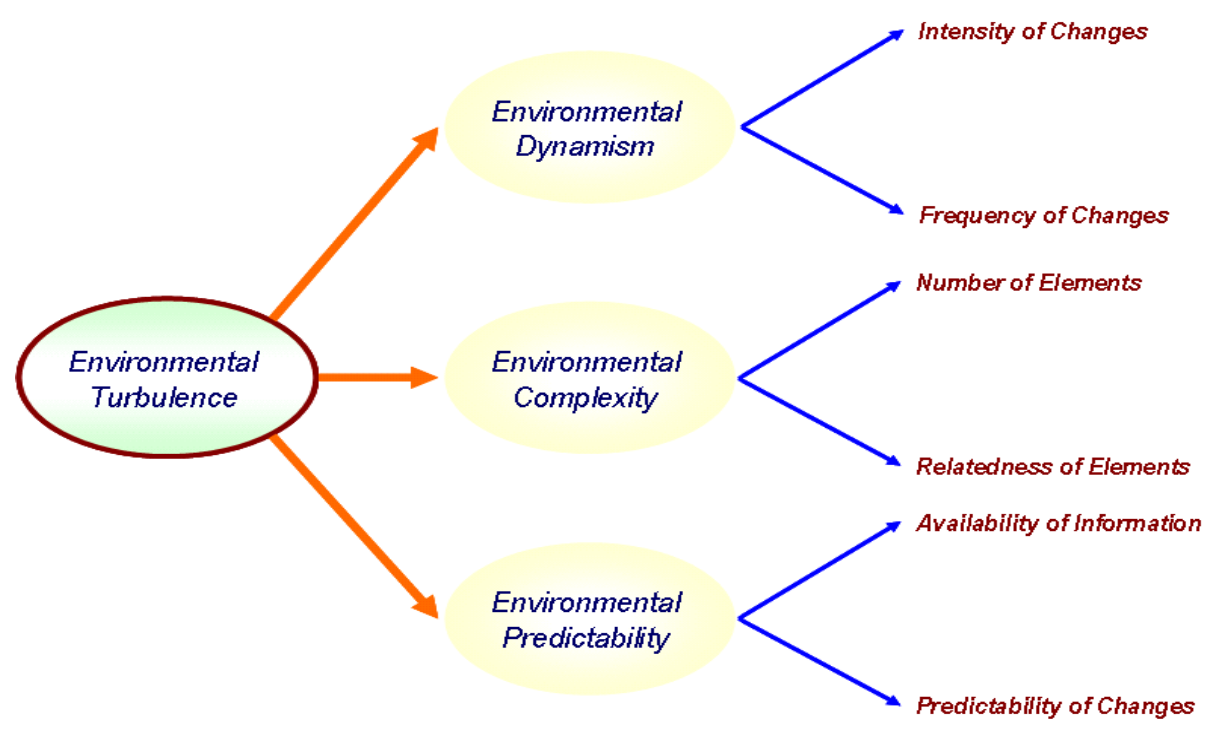

Figure 1. The Volberda \& Van Bruggen dimension of environmental turbulence

\subsubsection{Environmental Dynamism}

Environmental dynamism represents the rate of change in an environment. For example, Wijbenga and van Witteloostuijn (2007) defined environmental dynamism as the rate at which the preferences of customers and the services of organizations change over time. Li and Simerly (1998) refer to the rate of change and the level of factors instability within an environment. Iansity (1995) suggests that emergent levels of environmental dynamism lead to more uncertainty in service development, which also reduces the predictability and effects of change. Volberda \& Van Bruggen (1997: 138) state that there is two measurements of environmental dynamism which are called Intensity of Changes and Frequency of Changes.

\subsubsection{Environmental Complexity}

Complexity was defined by many researchers as one of the crucial factors of environments. Those researchers have also formulated different definitions of environmental complexity. Child (1972) described environmental complexity as heterogeneity and a range in the activities that are highly relevant to an organization's operations. Narayanan \& Nath (1993) explained that environmental complexity is a set of important environmental factors that affect the organization. Cannon \& John (2007: 299) confirm that the definition of environmental complexity composed three subdimensions. First of all, complexity is a function of the number of environmental components which the firm must include within it. Second, given some number of environmental components; complexity is a function of heterogeneity, dissimilarity, or diffusion among them. Third, given the presence of particular environmental components, complexity is a function of the sophisticated required interacting effectively with them. Black and Farias (1997) adopt a different approach to defining complexity, they affirm that complexity has five dimension: firm density (number of companies in the market), information density (amount of information in the market), clarity of information (embedded in the information flow of the system), path dependency (degree to which understanding and 
use of the information is dependent on previous use of similar information) and response time (rate of information dispersal between receiving and using it). According to Sia, et..al (2004) environmental complexity has higher uncertainty. Robbins \& Judge (2013: 533) mention that the environmental complexity is the degree of heterogeneity and concentration among environmental factors.

\subsubsection{Environmental Predictability}

Environmental Predictability as reflected by Thompson (1967: 85) represents the extent to which cause and effect relationships concerning environmental elements are incomplete. Child (1972) describes predictability as the degree of irregularity in the overall pattern of change. Volberda \& Van Bruggen (1997: 139) indicates that when changeovers of factors within environmental components are linear, or cyclical, or both, management can generalize future development.

\subsection{Entrepreneurial Orientation}

Lumpkin \& Dess (1996: 136) refer to Entrepreneurial Orientation (EO) as entrepreneurial activities; clarify how the entrepreneur undertakes the practices to act entrepreneurially. In regard to marketing approach, Covin and Miles (1999) define the term of Entrepreneurial Orientation as considering customers needs through innovation and creation of products, processes and strategies that satisfy customers. In another context, Ma'atoofi \& Tajeddini (2010: 255) considered Entrepreneurship Orientation as an approach focusing on the innovation in market-service and risky taking.

Entrepreneurial Orientation involves a willingness to innovate, search for risks, take self-directed actions, and be more proactive and aggressive than other competitors towards new marketplace opportunities (Wiklund \& Shepherd, 2005). Lumpkin \& Dess (2001) pinpoint five dimensions of entrepreneurial orientation: innovation, risk-taking, creativity, competitive aggressiveness, and autonomy. Innovation refers to firm's tendency to create, support new ideas and processes that may result in new services, or new solutions to problems and needs (Certo, et..al, 2009). Risk taking refers to organization's interest to enter in high-risk business to achieve their objectives (Lumpkin and Dess 2001). Creativity is an initiative against competitors aiming to defend and seek new opportunities to achieve the organization's leading competitive position through the introduction of new services (Morris, et..al, 2008). Competitive aggressiveness has been defined as an organization's predisposition to challenge competitors directly and to achieve superiority over them in the marketplace (Certo, et..al, 2009). Autonomy is an entrepreneurial initiative action to an idea, seeing it through to completion (Lumpkin and Dess, 1996).

\subsection{Innovation Performance}

According to Hariandja (2011: 405) performance variables measured in the hotel industry consist of two, i.e. objective and perception, because this industry is to commercialize the intangible experience. Objective performance variables consist of the occupancy per room, gross operating profits and gross operating profit per available room per day. Haber \& Reichel (2005) explained that the performance measurement must combine financial measures (revenue, cash flow, return on assets, return on equity) and non-financial measures (perceived market share, perceived sale growth, customer satisfaction, loyalty, and brand equity) to offer more comprehensive evaluation on firm's performance.

Innovative performance may vary along a newness continuum, ranging from radical to incremental (Laursen and Salter, 2006). Yet, Zhou, et..al (2011: 943), demonstrated that the measure of innovation performance required asking respondents to subdivide their present product range into three types of product. First, products that remained largely unchanged during the past 2 years. Second, products that were incrementally improved during the past 2 years. Third, products that were radically changed or introduced as entirely new products during the past 2 years. Others, such as Kirner, et..al (2009) for instance measured the innovation performance using three process innovation indicators: the production lead time, the employee productivity, and the rework or scrap rate. For another angle, Mankin (2007) also proposed that the innovation performance can be assessed using four measures: (1) Amount of ideas funded; (2) Return on investment or project net present value; (3) Innovators in higher positions/CEO devotion; and (4) Long-term customer adoption.

\subsection{Environmental Turbulence and Innovation Performance}

Many authors have found empirical support arguing that turbulent environments effected performance. Hashim, et..al. (2001) examined relationship between environmental complexity, strategy and performance through practice of 100 SMEs in manufacturing sector in Malaysia. The findings indicate that relationship between business strategy and performance of SME's moderated by environmental complexity. Mcnamara, et.al (2002) through using hierarchical regression to (76) top management teams from banks in three U.S found a significant relationship between the 
complexity of cognitive strategic groups and subsequent firm performance. Nadkarni \& Narayanan (2007) argued that turbulent and unpredictable environments affected firm's performance. Cannon \& John (2007) indicating that increased complexity was associated with decreased performance through evaluating the complexity-performance link from two perspectives: the first in which association with performance was assumed to be constant across all subdimensions of complexity, the second in which that assumption was relaxed.

Awang, et..al, (2008) confirms that hotel performance in Malaysia closely associated with the environment volatility rate. Akgün, et.al, (2008) discovered that the relationship between emotional capability and firm performance was influenced by the environmental dynamism including changes in industry, competition and consumer. Boyne \& Meier (2009) found that turbulence has a negative effect on performance, and that this is compounded by internal organizational change. Muglia (2010) findings support the previous studies that emphasize organizational environmental turbulence as a driving variable for management support and overall medical services process performance. Gül (2011) found that environmental dynamism has a positive effect on firm performance. Finally, Sabihaini (2012) discovered that the environmental complexity effected positively of banks performance. This leads to research proposition that can be formulated:

H1: Environmental Turbulence (Environmental Dynamism, Environmental Complexity and Environmental Predictability) has positive direct effect on Innovation Performance.

\subsection{Environmental Turbulence, Entrepreneuriale Orientation and Innovation Performance}

According to Davis, et..al (1991) from a survey involving personal interviews with managers in (93) firms representing six industries found that turbulence has a significant causal impact on entrepreneurship of the firm. Becherer \& Maurer (1997) discovered that both environmental turbulence and hostility are significantly related to entrepreneurial orientation. Zapalska, et.al, (2003) found various environmental factors affected Maori Entrepreneurs of New Zealand. In the same context, Ullah, et.al (2011) emphasized both environmental dynamism and environmental heterogeneity are significant predictors of entrepreneurial orientation and has a positive influence on it as well as highly correlated at (5\%) level of significance. Finally, Jalali (2012) found environmental determinants effected innovativeness and risk taking which are also two basic dimensions of entrepreneurial orientation.

Tang, et.al, (2007) based on a sample of (166) firms in Northern China found that there is a positive influence of entrepreneurial orientation on performance. Li, et.al, (2008) Indicated that entrepreneurial orientation is critical for enhancing firm performance. Wang (2008) Using data from (213) medium-to-large UK firms found there is a relationship between entrepreneurial orientation and Performance. Su, et..al, (2011) found the Entrepreneurial strategy making has a significant positive influence on firm performance. Hameed \& Ali (2011) revealed direct positive effect of innovativeness and risk-taking with firm's financial performance. Finally, Madhoushi, et..al, (2011) indicated that entrepreneurial orientation affected innovation performance. Jalali (2012) through using data from (183) decision makers in charge of exports in Iranian SME's in food industry found that innovativeness, as one of the EO dimensions, is the most effective strategy for SME's and help them to deal with the turbulent environmental condition and improve their export performance. Based on the discussion up, the researcher's points can be formulated the following proposition that express the basic research content:

H2: Environmental Turbulence (Environmental Dynamism, Environmental Complexity and Environmental Predictability) has positive indirect impact on Innovation Performance via Entrepreneurial Orientation.

Based on the literature review and hypotheses development above the researchers proposed a Hypothetical Model as clarify in Study Hypothetical Model part.

\section{Study Hypothetical Model}

The Study Hypothetical Model proposed guiding this research is depicted in Figure 2. As can be seen in the figure, we hypothesize Environmental Turbulence as a multi-dimensional construct consisting of three dimensions: Environmental Dynamism, Environmental Complexity and Environmental Predictability. These three dimensions were modeled with Innovation Performance as the dependent variable. 


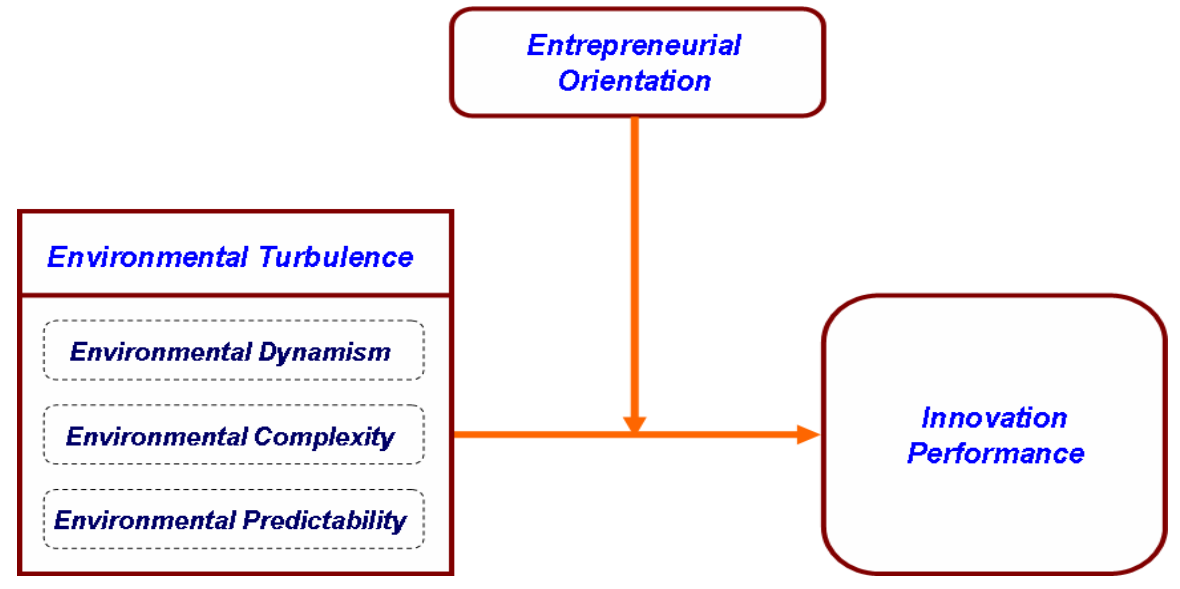

Figure 2. The study hypothetical model

We suggest Environmental Turbulence to be significant determinant of Innovation Performance i.e. more Environmental Turbulence lead to identify higher levels of Innovation performance. Thus, we propose that Entrepreneurial Orientation play a positive role in the relationship between environmental turbulence and innovation performance in five-star hotels in Jordan.

\section{Research Design}

This study is descriptive quantitative in nature, aiming to develop a better understanding of moderator effect of entrepreneurial orientation on the relationship between environmental turbulence and innovation performance from the managers and head of section point of view in five star hotels in Amman capital (Jordan).

\subsection{Measurement}

This study required developing a multidimensional Environmental Turbulence measurement scale and Entrepreneurial Orientation scale as well as Innovation Performance scale. As discussed in the above section, we have identified Environmental Turbulence to be multidimensional construct consisting of three dimensions: (Environmental Dynamism, Environmental Complexity and Environmental Predictability). This current study scale was adapting scale developed by Volberda \& Van Bruggen (1997). The scales measured in a five-point Likert-scale format from "Not Dynamism, Not Complex and Not Predictable" (1) to "Extremely Dynamism, Extremely Complex and Extremely Predictable" (5).The descriptive statistics of these dimensions presented in Appendix (1). For Entrepreneurial Orientation we use scale developed by Li, et..al, (2006) through five items. The scales also measured in a five-point Likert-scale format from "strongly disagree" (1) to "strongly agree" (5). The descriptive statistics of Entrepreneurial Orientation presented in Appendix (2). As well as, Innovation Performance scale in the current study was adapting scale suggested by Wang and Ahmed (2004) through four items. Similarly, the scales also measured in a five-point Likert-scale format from "strongly disagree" (1) to "strongly agree" (5). The descriptive statistics of Innovation Performance presented in Appendix (3).

\subsection{Sampling and Respondents Demographics}

The study is empirical based on the primary data collected from five star hotels in Amman capital at Jordan. Total of (13) five star hotels in Amman capital at Jordan were included in the study. In total (150) questionnaires were distributed to the managers and head of section. The number of usable returned questionnaires was (141) giving response rate (94\%), a rate that is regarded as good. A total of (141) answered questionnaires were retrieved, of which (6) were invalid, Therefore, (135) answered questionnaires were valid for study. A majority of the respondents $(76 \%)$ were male. $(60 \%)$ of the participants were aged between $(30-39)$ years. From the majority of educational level the results indicates that (74\%) having a bachelor degree, and the majority of the participants (73\%) with job experience between $(6-10)$ years. The result obtained for respondents demographics are depicted below in Table 1.

\subsection{Suitable Statistical Methods}

The statistical package for social science (SPSS “Ver. 20.0") and Amos (Ver. 20.0). Descriptive statistic analysis was performed to extract the frequencies, percentage, mean, standard deviation, one sample t-teat, acronbach's alpha of underlying study variables Environmental Turbulence, Entrepreneurial Orientation and Innovation Performance. As well as correlations, multiple regression analysis and structural equation modeling was performed to understand the relationship and effects among these variables. 
Table 1. Respondents demographics variables

\begin{tabular}{cccc}
\hline Variables & Category & Frequency & Percentage \\
\hline \multirow{2}{*}{ Gender } & Male & 102 & 76 \\
& Female & 33 & 24 \\
& Less than 30 & 22 & 16 \\
Age & Years & & 60 \\
& From 30 - 39 & 80 & 24 \\
& Above than 39 & 33 & 74 \\
Educational & BS & 100 & 4 \\
Level & High Diploma & 5 & 21 \\
& Master & 28 & 1 \\
& PhD & 2 & 3 \\
Job & 5 Years or Less & 4 & 73 \\
Experience & From 6 - 10 Years & 98 & 19 \\
& From 11 - 15 & 26 & 5 \\
\hline & years & 7 &
\end{tabular}

\section{Analysis and Results}

\subsection{Reliability, Correlations and Descriptive Statistic}

A Cronbach's coefficient Alpha was obtained to measure the reliability of all its item variables. According to Sekaran (2003), "Cronbach Alpha is a reliability coefficient that indicates how well the items are positively correlated to one another and closer the Cronbach's alpha is to (1), higher the internal consistency". Further Sekaran (2003) said that in general, the reliabilities less than (0.60) are considered to be poor, those in the (0.70) range, acceptable and those over (0.80) good .As the Cronbach's Alpha is above (0.80), thus internal reliability of the measures can be considered good. The result obtained for Cronbach's alpha test, Correlations and Descriptive statistic for the variables are depicted below in Table 2. Cronbach alpha reliability coefficients are at acceptable levels and fall between (0.839) for the Innovation Performance scale and (0.891) for Environmental Predictability. The overall questionnaire presented a Cronbach alpha of (0.935).

Table 2. Cronbach's alpha test, correlations and descriptive statistic

\begin{tabular}{|c|c|c|c|c|c|c|c|c|c|}
\hline Variables & $\begin{array}{l}\text { No. of } \\
\text { ítems }\end{array}$ & Cronbach alpha & Mean & $\mathrm{SD}$ & $\begin{array}{c}\text { Environmental } \\
\text { Dynamism }\end{array}$ & $\begin{array}{c}\text { Environmental } \\
\text { Complexity }\end{array}$ & $\begin{array}{c}\text { Environmental } \\
\text { Predictability }\end{array}$ & $\begin{array}{c}\text { Entrepreneurial } \\
\text { Orientation }\end{array}$ & $\begin{array}{c}\text { Innovation } \\
\text { Performance }\end{array}$ \\
\hline $\begin{array}{c}\text { Environmental } \\
\text { Dynamism }\end{array}$ & 7 & 0.879 & 4.10 & 0.46 & - & & & & \\
\hline $\begin{array}{c}\text { Environmental } \\
\text { Complexity }\end{array}$ & 4 & 0.859 & 4.06 & 0.62 & $0.485^{* *}$ & - & & & \\
\hline $\begin{array}{c}\text { Environmental } \\
\text { Predictability }\end{array}$ & 7 & 0.891 & 4.16 & 0.49 & $0.513^{* *}$ & $0.545^{* *}$ & - & & \\
\hline $\begin{array}{c}\text { Entrepreneuria } \\
\text { l Orientation }\end{array}$ & 5 & 0.866 & 4.03 & 0.58 & $0.463^{* *}$ & $0.533^{* *}$ & $0.608 * *$ & - & \\
\hline $\begin{array}{l}\text { Innovation } \\
\text { Performance }\end{array}$ & 4 & 0.839 & 4.00 & 0.59 & $0.502^{* *}$ & $0.676^{* *}$ & $0.520^{* *}$ & $0.615^{* *}$ & - \\
\hline
\end{tabular}

**Correlation is significant at the 0.01 level (2-tailed).

As can be seen in Table 2 with total mean scores (4.11) for total environmental turbulence, wherever form the first dimension of environmental turbulence - environmental dynamism - as can be seen in Table 2, with mean scores (4.10) on $(1-5)$ likert scale result indicate high extremely level of environmental dynamism in five star hotels at Amman capital in Jordan. Form the Second dimension of environmental turbulence - environmental complexity - as 
can be seen in Table 2, with mean scores $(4.06)$ on $(1-5)$ likert scale result indicate high extremely level of environmental complexity in five star hotels at Amman capital in Jordan. On the other hand, from environmental turbulence - environmental Predictability, with mean scores (4.16) on $(1-5)$ likert scale result indicate high extremely level of environmental Predictability in five star hotels at Amman capital in Jordan. As well as the mean scores of entrepreneurial orientation were (4.03) on $(1-5)$ likert scale that indicates high level of Entrepreneurial Orientation in five star hotels at Amman capital in Jordan. Finally, as can be seen in Table 2, the mean scores of Innovation Performance were (4.00) on (1 - 5) likert scale that indicates high level of Innovation Performance in five star hotels at Amman capital in Jordan.

From the other side, Table 2 clarifies the correlation coefficients between study variables. Where it is clear that there is a significant ten correlation varied in intensity they relate. It has been shown that the highest values correlated were among Environmental Complexity and Innovation Performance value of $\left(0.676^{* *}\right)$, with the lowest values correlated between Environmental Dynamism and Entrepreneurial Orientation value of $(0.463 * *)$. Overall, based on the results presented it is clear that the variables examined, interconnected moral relations which indicate that the increase or decrease in one of them would pull a result, an increase or decrease on other variables.

\subsection{Hypotheses Testing}

Through using multiple regressions analysis and structural equation modeling, we test the current study Hypotheses as seen below.

\subsubsection{Hypothesis One}

H1: Environmental Turbulence (Environmental Dynamism, Environmental Complexity and Environmental Predictability) has positive direct effect on Innovation Performance.

In order to test this hypothesis, we conducted a multiple regression analysis using Innovation Performance as the dependent variable, and the three dimensions of Environmental Turbulence: Environmental Dynamism, Environmental Complexity and Environmental Predictability as the predicting variables. Table 3 presents the regression results of the variables.

Table 3. Summary of multiple regression results - effect of environmental turbulence (environmental dynamism, environmental complexity and environmental predictability) on innovation performance in five star hotels at Amman capital in Jordan

\begin{tabular}{cccccccc}
\hline $\mathrm{R}$ & \multirow{2}{*}{$\mathrm{R}^{2}$} & $\mathrm{~F}$ & $\mathrm{Sig}^{*}$ & $\beta$ & & $\mathrm{T}$ & Sig* \\
\hline \multirow{2}{*}{0.705} & \multirow{2}{*}{0.497} & \multirow{2}{*}{22.729} & \multirow{2}{*}{0.000} & Dynamism & 0.305 & 2.346 & 0.022 \\
& & & & Complexity & 0.560 & 4.561 & 0.000 \\
& & & & Predictability & 0.317 & 2.638 & 0.018
\end{tabular}

Table 3 shows that Environmental Turbulence (Environmental Dynamism, Environmental Complexity and Environmental Predictability) has a significant positive effect on Innovation Performance in five star hotels in Amman capital of Jordan. The regression model achieve a high degree of fit, as reflected by " $\mathrm{R}$ " and " $\mathrm{R}$ " value $(0.705),(0.497)$, which asserted that $(0.497)$ of the explained variation in innovation performance can be accounted for Environmental Turbulence (Environmental Dynamism, Environmental Complexity and Environmental Predictability). On the other hand, Table 3 for the executive data set indicated the slope value of $(0.305),(0.560)$ and (0.317) for the regression line. This suggested that for a one unit increase in Environmental Turbulence (Environmental Dynamism, Environmental Complexity and Environmental Predictability) the respective organization can significantly predict a (0.305), (0.560) and (0.317) increase in innovation performance. As well as Table 3 shows that the analysis of variance of the fitted regression equation is significant with $F$ value of (22.729). This is an indication that the model is a good one. Since the p-value is less than (0.05), it shows a statistically significant relationship between the variables at (0.95) confidence level. The results also indicate that Environmental Turbulence (Environmental Dynamism, Environmental Complexity and Environmental Predictability) actually affect the innovation performance of five star hotels in Amman capital of Jordan with a coefficient of (0.305) for Environmental Dynamism, (0.560) for Environmental Complexity and (0.317) for Environmental Predictability. Thus, Environmental Turbulence (Environmental Dynamism, Environmental Complexity and Environmental Predictability) has a significant positive effect on Innovation Performance in five star hotels at Amman capital in Jordan. This further supported the study first hypothesis. 


\subsubsection{Hypothesis Two}

H2: Environmental Turbulence (Environmental Dynamism, Environmental Complexity and Environmental Predictability) has positive indirect effect on Innovation Performance via Entrepreneurial Orientation.

To test this hypothesis, we conducted a multiple regression analysis to identify the variation volume occur in case of the entrance moderator variable. And in the case, if the moderator variable has adjusted the affected result, we use the structural equation modeling (SEM) analysis. In accordance with Kim, et..al (2001: 65 - 68) that multiple regression analyses are useful to test moderating effects, SEM, which is based on maximum likelihood analysis, should be used if the model has multiple indicator variables for unobserved (or latent) variables. Table 4 presents the regression results.

Table 4. Summary of multiple regression results - effect of environmental turbulence on innovation performance via entrepreneurial orientation in five star hotels at Amman capital in Jordan

\begin{tabular}{|c|c|c|c|c|c|c|c|c|c|c|}
\hline Model & $\mathrm{R}$ & $\mathrm{R}^{2}$ & $\begin{array}{l}\text { Adjusted } \\
\mathrm{R}^{2}\end{array}$ & $\begin{array}{c}\mathrm{R}^{2} \\
\text { Change }\end{array}$ & $\begin{array}{c}\mathrm{F} \\
\text { Change }\end{array}$ & $\begin{array}{c}\text { Sig. } \\
\text { F } \\
\text { Change }\end{array}$ & $\beta$ & & $\mathrm{T}$ & Sig* \\
\hline \multirow{2}{*}{1} & \multirow{2}{*}{0.705} & \multirow{2}{*}{0.497} & \multirow{2}{*}{0.475} & \multirow{2}{*}{0.497} & \multirow{2}{*}{22.729} & \multirow{2}{*}{0.000} & Dynamism & 0.305 & 2.346 & 0.022 \\
\hline & & & & & & & Complexity & 0.560 & 4.561 & 0.000 \\
\hline \multirow[b]{2}{*}{2} & \multirow[b]{2}{*}{0.759} & \multirow[b]{2}{*}{0.575} & \multirow[b]{2}{*}{0.550} & \multirow[b]{2}{*}{0.078} & \multirow[b]{2}{*}{12.552} & \multirow[b]{2}{*}{0.001} & Predictability & 0.312 & 2.483 & 0.014 \\
\hline & & & & & & & $\begin{array}{l}\text { Entrepreneurial } \\
\text { Orien }\end{array}$ & 0.365 & 3.543 & 0.001 \\
\hline
\end{tabular}

Table 4 clarifies that the entrance Entrepreneurial Orientation (moderator variable) between Environmental Turbulence (independent variable) and Innovation Performance (dependent variable) improved significant the $\mathrm{R}^{2}$ value (0.078) as well as the improved significance illustrated through change value in $F$ value (12.552) which means continuation in analysis process through transition to structural equation modeling analysis using Amos program.

Before testing the $\boldsymbol{H} \mathbf{2}$ hypothesis, maximum likelihood Method was used to conduct the analysis through obtaining a number of goodness of fitness indices for the model fitness, the early model-fit indices that chi square $\chi 2$ value was (110.231) $(\mathrm{df}=1, \mathrm{p}=0.000)$, goodness-of -fit index "GFI" was (0.638), comparative fit index (CFI) was (0.395), and the root mean square residual (REMSA) was (0.491), which indicate poor-fit indices. So the null hypothesis of the model is rejecting and there is room for refinement, which all of it out of the acceptable range. As shown in Table 5 and Figure 3.

Table 5. Summary indicators for model-fit indices

\begin{tabular}{|c|c|c|c|c|}
\hline Fit Indices & \multicolumn{3}{|c|}{ Recommended value } & Values obtained \\
\hline \multicolumn{2}{|l|}{$\chi^{2}$} & \multicolumn{2}{|l|}{$\leq 3.00$} & 110.231 \\
\hline \multicolumn{2}{|l|}{ GFI } & \multicolumn{2}{|l|}{$\geq 0.90$} & 0.638 \\
\hline \multicolumn{2}{|l|}{ CFI } & \multicolumn{2}{|l|}{$\geq 0.90$} & 0.395 \\
\hline \multicolumn{2}{|l|}{ RMSEA } & \multicolumn{2}{|l|}{$\leq 0.08$} & 0.491 \\
\hline \multicolumn{5}{|l|}{$\begin{array}{c}\text { Environmental } \\
\text { Dynamism }\end{array}$} \\
\hline $\begin{array}{l}\text { Environmental } \\
\text { Complexity }\end{array}$ & 0.13 & $\begin{array}{l}\text { Entrepreneurial } \\
\text { Orientation }\end{array}$ & 0.62 & $\begin{array}{c}\text { Imnovation } \\
\text { Performance }\end{array}$ \\
\hline $\begin{array}{l}\text { Environmental } \\
\text { Predictability }\end{array}$ & & & & \\
\hline
\end{tabular}

Figure 3. Proposed study model 
After that number of modified indicators were done in order to enhance the model fitness, some of relationships were added between the independent variables, as well as many of path coefficient were added between the independent and dependent variable, as represent in Table 6.

Table 6. Results of relationships and path coefficient were added

\begin{tabular}{|c|c|c|c|c|c|c|}
\hline & & & Estimate & S.E & C.R & $\mathrm{P}$ \\
\hline Dynamism & $\leftrightarrow$ & Complexity & 0.225 & 0.036 & 3.779 & $* * *$ \\
\hline Dynamism & $\leftrightarrow$ & Predictability & 0.135 & 0.028 & 2.091 & 0.033 \\
\hline Complexity & $\leftrightarrow$ & Predictability & 0.115 & 0.026 & 2.018 & 0.044 \\
\hline Predictability & $\cdots$ & Innovation Performance & 0.183 & 0.741 & 2.213 & 0.014 \\
\hline Complexity & 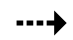 & Innovation Performance & 0.544 & 0.551 & 2.972 & 0.010 \\
\hline
\end{tabular}

From the Table 6 three relationships between the independent variables were added and two path coefficient were added, all new relationship and path coefficient were statistically significant at level 0.05 . After that the fitness indices were tested another time the results shows chi square $\chi^{2}$ value was $(0.136)(\mathrm{DF}=1, \mathrm{p}=0.713)$, goodness-of -fit index "GFI" was (0.983), comparative fit index (CFI) was (0.967), and the root mean square residual (REMSA) was (0.000), which indicate good-fit indices, so that the hypothesis of the model is accepted which all of it within the acceptable range. As shown in Figure 4.

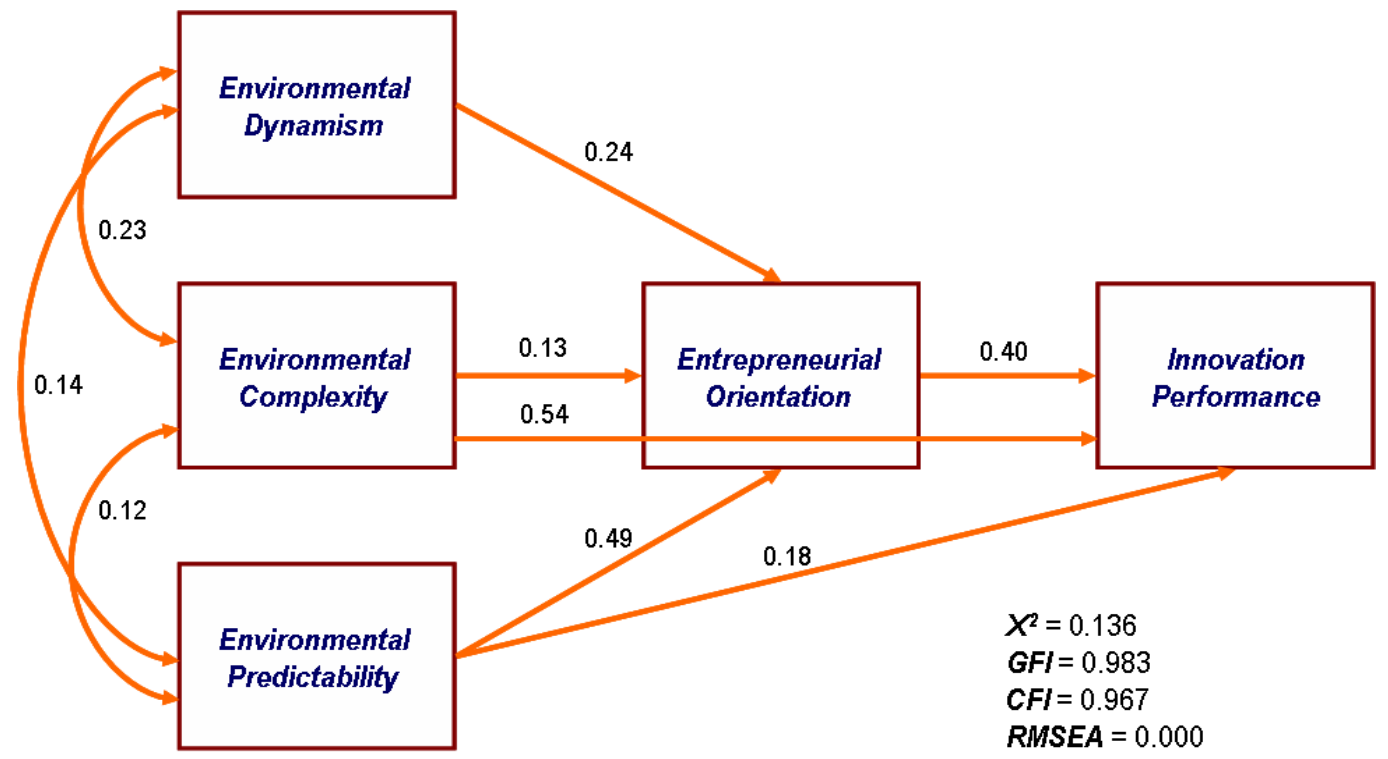

Figure 4. Modify study model

As shown in Figure 4, all model-fit indices exceeded their respective common acceptance level; the measurement model exhibited a fairly good fit with the data collected. As shown in Table 7. 
Table 7. Path coefficient and $\mathrm{t}$ value for the effect of environmental turbulence (environmental dynamism, environmental complexity and environmental predictability) on innovation performance via entrepreneurial orientation

\begin{tabular}{|c|c|c|c|c|c|c|}
\hline & & & Estimate & S.E & C.R & $\mathrm{P}$ \\
\hline Dynamism & $\cdots$ & $\begin{array}{c}\text { Entrepreneurial } \\
\text { Orientation }\end{array}$ & 0.238 & 0.674 & 2.710 & 0.021 \\
\hline Predictability & $\cdots$ & $\begin{array}{c}\text { Entrepreneurial } \\
\text { Orientation }\end{array}$ & 0.488 & 0.819 & 2.891 & 0.017 \\
\hline Complexity & $\cdots$ & $\begin{array}{c}\text { Entrepreneurial } \\
\text { Orientation }\end{array}$ & 0.129 & 0.637 & 2.021 & 0.031 \\
\hline $\begin{array}{c}\text { Entrepreneurial } \\
\text { Orientation }\end{array}$ & $\cdots$ & Innovation Performance & 0.402 & 0.492 & 2.522 & 0.028 \\
\hline
\end{tabular}

From the Table 7 it was clarify that the effect value of environmental turbulence dimensions (dynamism, Complexity and Predictability) on entrepreneurial orientation in five-star hotels in Jordan was $(0.238,0.129,0.488)$ and the $t$ value was $(2.710,2.021,2.891)$ with $\mathrm{p}$ level $(0.021,0.031,0.017)$ which means the environmental turbulence dimensions (dynamism, Complexity and Predictability) have a significant effect on entrepreneurial orientation in five-star hotels in Jordan. As well as, the effect value of entrepreneurial orientation on innovation performance in five-star hotels in Jordan was (0.402) and the $t$ value was (2.522) with $p$ level (0.028) which means the entrepreneurial orientation have a significant effect on innovation performance in five-star hotels in Jordan.

\section{Conclusions and Implications}

This study provides an empirical study of the moderator effect of entrepreneurial orientation on the relationship between environmental turbulence and innovation performance in five-star hotels in Jordan. We consider environmental turbulence dimensions as independent variables affected by innovation performance. As well as, the entrepreneurial orientation playing a positive role in the relationship between environmental turbulence and innovation performance.

The results of the multiple regression analyses provide support for the two hypothesized. Consistent with $\boldsymbol{H}$, Environmental Turbulence (Environmental Dynamism, Environmental Complexity and Environmental Predictability) has positive effect on Innovation Performance. This result is consistent with Nadkarni \& Narayanan (2007) arguing that turbulent and unpredictable environments effected firm's performance, Cannon \& John (2007) that indicating the increased complexity was associated with decreased performance, Muglia (2010) that finding organizational environmental turbulence as a driving variable for management support and overall medical services process performance..

In accordance with $\boldsymbol{H 2}$, Environmental Turbulence (Environmental Dynamism, Environmental Complexity and Environmental Predictability) has positive indirect effect on Innovation Performance via Entrepreneurial Orientation. This result is consistent with Ullah, et..al (2011) who emphasized that environmental dynamism and environmental heterogeneity are significant predictors of entrepreneurial orientation and Jalali (2012) that found innovativeness, as one of the EO dimensions, is the most effective strategy for SME's and help them to deal with the turbulent environmental condition and improve their export performance.

Therefore, five star hotels in Amman capital of Jordan managers and decision makers can use the current findings to understand the role of Entrepreneurial Orientation to increase Innovation Performance and the effect of Environmental Dynamism, Complexity and Predictability. The current findings may be used by managers and head of section to differentiate themselves in hospitality tourism industry marketplace. To remain superiority and obtain highly performance, managers and head of section of hospitality tourism industry in Jordan can try to increase innovation performance by managing each dimension of Environmental Turbulence i.e. Environmental Dynamism, Environmental Complexity and Environmental Predictability in the context of hospitality tourism industry and understanding the role of Entrepreneurial Orientation in increase and maintenance innovation performance.

\section{References}

Akgün, Ali E., Keskin, Halit, \& Byrne John. (2008). The moderating role of environmental dynamism between firm emotional capability and performance. Journal of Organizational Change Management, 21(2), $230-25$. http://dx.doi.org/10.1108/09534810810856453 
Ansoff, I., \& McDonnell, E. (1990). Implementing Strategic Management $\left(2^{\text {nd }}\right.$ ed.). Prentice Hall International (U.K.) Ltd.

Awang, Khairil Wahidin, Ishak, Nor Khomar, Radzi, Salleh Mohd, \& Taha, Azni Zarina. (2008). Environmental Variables and Performance: Evidence from the Hotel Industry in Malaysia. International Journal of Economics and Management, 2(1), 59-79.

Becherer, Richard C., \& Maurer, John G. (1997). The Moderating Effect of Environmental Variables on the Entrepreneurial and Marketing Orientation of Entrepreneur-led Firms. Entrepreneurship Theory and Practice, $22(1), 47-58$.

Black, J., \& Farias, G. (1997). Genesis of Complexity Cycles. Paper read at Eighth Annual International Conference of The Society for Chaos Theory in Psychology and life Sciences, Boston University, Boston, 31 July.

Boyne, George A., \& Meier, Kenneth J. (2009). Environmental Turbulence, Organizational Stability, and Public Service Performance. Administration \& Society, 40(8), 799-824. http://dx.doi.org/10.1177/0095399708326333

Cannon, Alan R., \& John, Caron H. St. (2007). Measuring Environmental Complexity: A Theoretical and Empirical Assessment. Organizational Research Methods, 10(2), 296-321. http://dx.doi.org/10.1177/1094428106291058

Certo, S. T., Moss, T. W., \& Short, J. C. (2009). Entrepreneurial orientation: An applied perspective. Business Horizons, 52(4), 319-324. http://dx.doi.org/10.1016/j.bushor.2009.02.001

Child, J. (1972). Organizational structure, environment and performance. Sociology, 6, 2-22. http://dx.doi.org/10.1016/j.bushor.2009.02.001

Covin, J. G., \& Miles, M. P. (1999). Corporate entrepreneurship and the pursuit of competitive advantage. Entrepreneurship Theory and Practice, 23(3), 47-65.

Davis, Duane, Morris, Michael, \& Allen, Jeff. (1991). Perceived Environmental Turbulence and Its Effect on Selected Entrepreneurship, Marketing, and Organizational Characteristics in Industrial Firms. Journal of the Academy of Marketing Science, 19(1), 43-51. http://dx.doi.org/10.1007/BF02723423

Gül, Mısra Çağla. (2011). Environmental Dynamism, Innovativeness and Firm Performance. The 2011 Las Vegas International Academic Conference, Las Vegas, Nevada: 683-690.

Haber, S., \& Reichel, A. (2005). Identifying performance measures of small ventures: The case of the tourism industry. Journal of Small Business Management, 43(3), 257-286. http://dx.doi.org/10.1111/j.1540-627X.2005.00137.x

Hameed, Imran, \& Ali, Bakhtiar. (2011). Impact of Entrepreneurial Orientation, Entrepreneurial Management and Environmental Dynamism on Firm's Financial Performance. Journal of Economics and Behavioral Studies, 3(2), 101-114.

Hariandja, Evo Sampetua. (2011). The Relationship Between Service Innovation, Marketing Communication, and Performance in Hospitality Industries - A Conceptual Framework. Proceeding of Industrial Engineering and Service Science, September 20-21, 403-408.

Hashim, M. K., Wafa, S. A., \& Sulaiman. (2001). Testing Environment as Mediator Between Business Strategy Performance Relationship: A Study on Malaysian SMEs. 46 ${ }^{\text {th }}$ ICSB World Conference - January 17-20 2001, Taipei, Taiwan.

Iansity, M. (1995). Technology integration: Managing technological evolution in a complex environment. Research Policy, 24, 521-542. http://dx.doi.org/10.2307/41165820

Jalali, Seyed Hossein. (2012). Environmental Determinants, Entrepreneurial Orientation and Export Performance: Empirical Evidence from Iran. Serbian Journal of Management, 7(2), 245-255. http://dx.doi.org/10.5937/sjm7-1687

Kim, Jin-Sun, Judy, Kaye, \& Lore K. Wright. (2001). Moderating and Mediating Effects in Causal Models. Issues in Mental Health Nursing, 22, 63-75. http://dx.doi.org/10.1080/01612840121087

Kirner, E., Kinkel, S., \& Jaeger, A. (2009). Innovation paths and the innovation performance of low-technology firms - an empirical analysis of German industry. Research Policy, 38, 447-458. http://dx.doi.org/10.1016/j.respol.2008.10.011

Laursen, K., \& A. Salter. (2006). Open for Innovation: The Role of Openness in Explaining Innovation Performance among U.K. Manufacturing Firms. Strategic Management Journal, 27(2), 131-150. http://dx.doi.org/10.1002/smj.507 
Li, M., \& Simerly, R.L. (1998). The moderating effect of environmental dynamism on the ownership and performance relationship. Strategic Management Journal, 19, 169-179. http://dx.doi.org/10.1002/(SICI)1097-0266(199802)19:2<169::AID-SMJ939>3.0.CO;2-2

Li, Yong-Hui, Huang, Jing -Wen, \& Tsai, Ming -Tien. (2008). Entrepreneurial orientation and firm performance: The role of knowledge creation process. Industrial Marketing Management, 38(4), 1-10. http://dx.doi.org/10.1016/j.indmarman.2008.02.004

Li, Yuan, Liu, Yi, \& Zhao, Yongbin. (2006). The role of market and entrepreneurship orientation and internal control in the new product development activities of Chinese firms. Industrial Marketing Management, 35(3), 336-347. http://dx.doi.org/10.1016/j.indmarman.2005.05.016

Lumpkin, G., \& Dess, G.G. (1996). Clarifying the entrepreneurial orientation construct and linking it to performance. Academy of Management Review, 21(1), 135-172. http://dx.doi.org/10.5465/AMR.1996.9602161568

Lumpkin, G., \& Dess, G.G. (2001). Linking two dimensions of entrepreneurial orientation to firm performance: The moderating role of environment and industry life cycle. Journal of Business Venturing, 16(5), 429-451. http://dx.doi.org/10.1016/S0883-9026(00)00048-3

Ma'atoofi, Ali Reza, \& Tajeddini, Kayhan. (2010). The Effect of Entrepreneurship Orientation on Learning Orientation and Innovation: A Study of Small-Sized Business Firms in Iran. International Journal of Trade, Economics and Finance, 1(3), 254-260. http://dx.doi.org/10.7763/IJTEF.2010.V1.46

Madhoushi, Mehrdad, Sadati, Abdolrahim, Delavari, Hamidreza, Mehdivand, Mohsen, \& Mihandost, Ramin. (2011). Entrepreneurial Orientation and Innovation Performance: The Mediating Role of Knowledge Management. Asian Journal of Business Management, 3(4), 310-316.

Mankin, E. (2007). Measuring innovation performance. Research Technology Management, 50(6), 5-7.

McNamara, Gerry M., Luce, Rebecca A., \& Tompson, George H. (2002). Examining the Effect of Complexity in Strategic Group Knowledge Structures on Firm Performance. Strategic Management Journal, 23(2), 153-170. http://dx.doi.org/10.1002/smj.211

Morris, M.H., Kuratko, D.F., \& Covin, J.G. (2008). Corporate entrepreneurship and innovation ( ${ }^{\text {nd }}$ ed.). Thompson South-Western.

Muglia, Victor O. (2010). The Relationship between Environmental Turbulence, Management Support, Organizational Collaboration, Information Technology Solution Realization, and Process Performance, in Healthcare Provider Organizations. Doctoral Dissertation, Alliant International University, San Diego, U.S.A.

Nadkarni, S., \& Narayanan, V.K. (2007). Strategic Schemas, Strategic Flexibility, and Firm Performance: The Moderating Role of Industry Clockspeed. Strategic Management Journal, 28, 243-270. http://dx.doi.org/10.1002/smj.576

Narayanan, V., \& Nath, R. (1993). Organization Theory: A Strategic Approach. Boston: Richard D, Irwin, Inc.

Robbins, Stephen P., \& Judge, Timothy A. (2013). Organizational Behavior (15 ${ }^{\text {th }}$ ed.). Pearson Education Limited, England.

Sabihaini. (2012). Environmental and Strategy Changing and the Implications on Performance in the Banking Sector. International Journal of Business and Management Tomorrow, 1(2), 1-31.

Samli, A.C. (1993). Counter turbulence Marketing: A Proactive Strategy for Volatile Economic Times. Westport: Quorum Books.

Sekaran, U. (2003). Research Methods for Business: A Skill-building Approach. New York: Wiley.

Sia, C., Teo, H., Tan, B.C.Y., \& Wei, K. (2004). Effects of environmental uncertainty on organizational intention to adopt distributed work arrangements. IEEE Transactions on Engineering Management, 51(3), 253-267. http://dx.doi.org/10.1109/TEM.2004.830859

Smith, M.F., Sinha, I., Lancioni, R., \& Forman, H. (1999). Role of Market Turbulence in Shaping Pricing Strategy. Industrial Marketing Management, 28, 637 - 649. http://dx.doi.org/10.1016/S0019-8501(98)00037-6

$\mathrm{Su}$, Zhongfeng, Xie, En, Wang, Dong, \& Li, Yuan. (2011). Entrepreneurial strategy making, resources, and firm performance: evidence from China. Small Business Economics, 36, 235-247. http://dx.doi.org/10.1007/s11187-009-9211-9 
Tang, Jintong, Tang, Zhi, Zhang, Yuli, \& Li, Qianwen. (2007). The Impact of entrepreneurial orientation and Ownership Type on Firm Performance in the Emerging Region of China. Journal of Developmental Entrepreneurship, 12(4), 383-397. http://dx.doi.org/10.1142/S1084946707000733

Thompson, J.D. (1967). Organizations in action. New York: McGraw-Hill.

Ullah, Hafiz, Shah, Bahadar, Hassan, Faqir Sajjad Ul, \& Zaman, Tariq. (2011). Environment related factors affecting the entrepreneurial orientation: Evidence from Khyber Pakhtunkhwa-Pakistan. International Journal of Education and Social Sciences, 1(1), 1-19.

Volberda, H.W., \& Van Bruggen, G.H. (1997). Environmental turbulence: A Look into its dimensionality. NOBO-onderzoekdag, 137-145.

Vorhies, DW. (1998). An investigation of the factors leading to the development of marketing capabilities and organizational effectiveness. Journal of Strategic Marketing, 6, 3-23. http://dx.doi.org/10.1080/096525498346676

Wang, C. L. (2008). Entrepreneurial orientation, learning orientation, and firm performance. Entrepreneurship Theory and Practice, 32(4), 635-656. http://dx.doi.org/10.1111/j.1540-6520.2008.00246.x

Wang, C. L., \& Ahmed, P. K. (2004). The development and validation of the organizational innovativeness construct using confirmatory factor analysis. European Journal of Innovation Management, 7(4), 303-313. http://dx.doi.org/10.1108/14601060410565056

Wijbenga, F. H., \& Van, Witteloostuijn, A. (2007). Entrepreneurial locus of control and competitive strategies -The moderating effect of environmental dynamism. Journal of Economic Psychology, 28, 566-589. http://dx.doi.org/10.1016/j.joep.2007.04.003

Wiklund, J., \& Shepherd, D. (2005). Entrepreneurial orientation and small business performance: A configuration approach. Journal of Business Venturing, 20, 71-91. http://dx.doi.org/10.1016/j.jbusvent.2004.01.001

Zapalska, Alina M., Dabb, Helen, \& Perry, Geoff. (2003). Environmental Factors Affecting Entrepreneurial Activities: Indigenous Maori Entrepreneurs of New Zealand. Asia Pacific Business Review, 10(2), 160-177. http://dx.doi.org/10.1080/13602380410001677191

Zhou, Haibo, Dekker, Ronald, \& Kleinknechty, Alfred. (2011). Flexible labor and innovation performance: evidence from longitudinal firm-level data. Industrial and Corporate Change, 20(3), 941-968. http://dx.doi.org/10.1093/icc/dtr013

Apendex 1. Descriptive statistics of three environmental turbulence dimensions

\begin{tabular}{clcc}
\hline No. & \multicolumn{1}{c}{ Environmental Turbulence } & Mean & $\begin{array}{c}\text { Standard } \\
\text { Deviation }\end{array}$ \\
\hline 1 & Changes in our market are very intense & 4.37 & 0.94 \\
\hline 2 & $\begin{array}{l}\text { Our customers regularly ask for complete new } \\
\text { services }\end{array}$ & 4.00 & 0.97 \\
\hline 3 & Our market can be characterized by more of the same & 4.15 & 0.99 \\
\hline$\quad$ Mean \& St.D of Dynamism - Intensity of Changes & 4.17 & 0.71 \\
\hline 4 & In our market changes are taking place continuously & 3.97 & 1.01 \\
\hline 5 & Within a year nothing will have changed in our market & 4.13 & 0.98 \\
\hline 6 & Our supply of services changes continuously & 3.93 & 1.01 \\
\hline 7 & $\begin{array}{l}\text { In our market the volumes of services to be delivered } \\
\text { changes fast }\end{array}$ & 4.10 & 0.97 \\
\hline$\quad$ Mean \& St.D of Dynamism - Frequency of Changes & 4.03 & 0.54 \\
\hline$\quad$ Mean \& St.D of total Environmental Dynamism & 4.10 & 0.46 \\
\hline 8 & $\begin{array}{l}\text { In marketing decisions in our market a lot of variables } \\
\text { should be taken into consideration }\end{array}$ & 3.93 & 1.10 \\
\hline 9 & $\begin{array}{l}\text { In our market developments are taking place which } \\
\text { stem from all kind of directions }\end{array}$ & 4.18 & 0.98 \\
\hline$\quad$ Mean \& St.D of Complexity - Number of elements & 4.05 & 0.81 \\
\hline 10 & In our market everything is related to everything & 4.22 & 0.92 \\
\hline 11 & A decision in our market influences a large number of & 3.92 & 1.00 \\
\hline
\end{tabular}




\begin{tabular}{|c|c|c|c|}
\hline \multicolumn{4}{|c|}{ factors } \\
\hline & Mean \& St.D of Complexity - Relatedness of elements & 4.07 & 0.79 \\
\hline & Mean \& St.D of total Environmental Complexity & 4.06 & 0.62 \\
\hline 12 & $\begin{array}{l}\text { Nothing of what happens in our market will stay a } \\
\text { secret for us }\end{array}$ & 4.10 & 0.99 \\
\hline 13 & $\begin{array}{l}\text { Information we need about our market we will always } \\
\text { get }\end{array}$ & 4.34 & 0.93 \\
\hline 14 & $\begin{array}{l}\text { it is hard in this market to base decisions on reliable } \\
\text { information }\end{array}$ & 4.16 & 0.96 \\
\hline 15 & $\begin{array}{l}\text { We have sufficient insight and information about who } \\
\text { our customers are }\end{array}$ & 3.96 & 1.01 \\
\hline \multicolumn{2}{|r|}{ Mean \& St.D of Predictability - Availability of information } & 4.14 & 0.56 \\
\hline 16 & There is a clear trend in the changes in our market & 4.15 & 0.98 \\
\hline 17 & $\begin{array}{l}\text { Although a lot changes in our market, it will always be } \\
\text { possible to discover a pattern in these changes }\end{array}$ & 4.16 & 0.97 \\
\hline 18 & The entrance and exit of competitors is foreseeable & 4.25 & 0.94 \\
\hline \multicolumn{2}{|r|}{ Mean \& St.D of Predictability - Predictability of changes } & 4.19 & 0.66 \\
\hline \multicolumn{2}{|r|}{ Mean \& St.D of total Environmental Predictability } & 4.16 & 0.49 \\
\hline & Mean \& St.D of total Environmental Turbulence & 4.11 & 0.43 \\
\hline
\end{tabular}

Apendex 2. Descriptive statistics of entrepreneurial orientation

\begin{tabular}{cllcc}
\hline No. & \multicolumn{1}{c}{ Entrepreneurial Orientation } & Mean & $\begin{array}{c}\text { Standard } \\
\text { Deviation }\end{array}$ \\
\hline 1 & $\begin{array}{l}\text { a strong emphasis on R\&D, technological } \\
\text { leadership and innovation }\end{array}$ & 4.19 & 0.95 \\
\hline 2 & $\begin{array}{l}\text { a strong tendency for high-risk NSD projects } \\
\text { which have a chance of very high returns }\end{array}$ & 4.10 & 0.97 \\
\hline $\begin{array}{l}\text { a tendency to initiate action that competitors } \\
\text { respond to }\end{array}$ & 3.90 & 0.99 \\
\hline 4 & $\begin{array}{l}\text { a tendency to be a leader, always introducing new } \\
\text { service or technology first }\end{array}$ & 4.07 & 0.98 \\
\hline 5 & $\begin{array}{l}\text { a tendency to adopt a competitive } \\
\text { "undo-the-competitors" posture }\end{array}$ & 3.88 & 1.03 \\
\hline & Mean \& St.D of Entrepreneurial Orientation & 4.03 & 0.58 \\
\hline
\end{tabular}

Apendex 3. Descriptive statistics of innovation performance

\begin{tabular}{clcc}
\hline No. & \multicolumn{1}{c}{ Innovation Performance } & Mean & $\begin{array}{c}\text { Standard } \\
\text { Deviation }\end{array}$ \\
\hline 1 & $\begin{array}{l}\text { In new service introductions, our hotels is often } \\
\text { first-to market }\end{array}$ & 4.16 & 0.93 \\
\hline 2 & $\begin{array}{l}\text { Our new services are often perceived very novel } \\
\text { by customers }\end{array}$ & 3.99 & 0.99 \\
\hline $\begin{array}{l}\text { We are constantly improving our business } \\
\text { processes }\end{array}$ & 3.96 & 1.08 \\
\hline $\begin{array}{l}\text { During the past five years, our hotels has } \\
\text { developed many new management approaches }\end{array}$ & 3.90 & 1.02 \\
\hline & Mean \& St.D of Innovation Performance & 4.00 & 0.59 \\
\hline
\end{tabular}

